\title{
Changeability in Stripe Rust Infection and Grain Yield of Wheat Associated to Climatic Conditions
}

\author{
Ibrahim Draz ${ }^{*}$, Samar Esmail ${ }^{1}$, Mohamed Abou-Zeid ${ }^{1}$ and Yasser Hafez ${ }^{2}$ \\ ${ }^{1}$ Wheat Disease Research Department, Plant Pathology Research Institute, \\ Agricultural Research Center, Giza, Egypt. \\ ${ }^{2}$ EPCRS Excellence Center \& Plant Pathology and Biotechnology Lab., Agricultural \\ Botany Department, Faculty of Agriculture, Kafrelsheikh University, Egypt.
}

\begin{abstract}
T TRIPE rust infection caused by Pucciniastrii formis f. sp. tritici was investigated

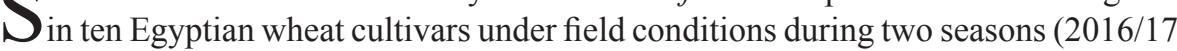
and 2017/18) at two locations (Sakha and Sids) differ climatologically in Egypt. Variable levels of rust infection followed by a significant reduction in grain weight were recorded at both locations. Stripe rust infections for Sids location (20S - 90S) were higher than those of Sakha location (TrMS - 70S). Average coefficient of infection (ACI) and grain weight loss for Sids location, reaching 90 ACI (Gemmeiza-11) and $23.12 \%$ (Giza-160), were higher than those of Sakha location up to $70 \mathrm{ACI}$ and $16.72 \%$ in Giza-160. Grain weight loss was strongly associated with ACI among cultivars for both locations, recording $r=0.9044$ for Sakha location and $r=0.8866$ for Sids location. Climatic variations were recorded at both locations during the first four months of 2017 and 2018. Rainfall and relative humidity for Sakha location were higher than those of Sids location while wind speed for Sids location was higher than that of Sakha location. Temperatures were relatively close at both locations. ACI values for Sids location were higher than those of Sakha location, revealing correlation with climatic factors. This suggests that wind speed may play an important role in dispersal while relatively heavy rainfall may have opposing effects. The temperature was the main limiting factor for stripe rust infection (negatively associated), followed by relative humidity (positively associated). Our discovery represents a powerful tool for predicting disease infection and management.
\end{abstract}

Keywords: Wheat, Stripe rust, Climatic conditions, Disease infection, Yield loss.

\section{Introduction}

Stripe (yellow) rust caused by Puccinia striiformis f. sp. tritici (Pst), is one of the most important diseases of wheat (Triticum aestivum L.) incurred great yield losses around the world (Hovmøller et al. 2010, 2011; de Vallavieille-Pope et al. 2012; Chen et al. 2014). In Egypt, the disease affected most of the Egyptian wheat cultivars, since major epiphytotics have been recorded once in every decade since the Sixties, causing grain yield loss ranged from $14 \%$ to $26 \%$ in the Nile Delta region while the countrywide loss was $10 \%$ (El-Daoudi et al. 1996). The causal fungus Pst is present in wheat growing areas of temperate, moist, and cooler regions of the world (Chen 2005). In the highly susceptible varieties, yield loss may reach 80\% (Kolmer 1996; Beard et al.
2007). The most economical and environmentfriendly measure for disease management is developing and deploying the resistant wheat genotypes (Singh et al. 2004; Draz et al. 2015). Resistance wheat genotypes could be created through introgression into different varieties and subsequent evaluation for field resistance. The field resistance level of a set of numerous varieties/breeding lines is assessed through their severity and host reaction at adult plant stage. Host reaction is the phenotype resulting from the interaction after Pst infection as responded by the host defense mechanism and is termed a hostpathogen interaction phenotype (Draz 2019). The ability of stripe rust to infect wheat plants depends on many factors, including host resistance, time of infection, and environmental factors (Sharma-

*Corresponding author e-mail: dr.ibrahim draz@yahoo.com 
Poudyal and Chen 2011). The infection process of stripe rust is affected by different climatic factors (de Vallavieille-Pope et al. 1995, 2012). The main climatic factors affecting disease severity are moisture, temperature, and wind (Lyon andBroders 2017). The host-pathogen gene pairs related to resistance response, have been shown to be affected by temperature range, reported for another related wheat-Puccinia triticina system (Browder and Eversmeyer 1986). Stripe rust of wheat needs free moisture (high humidity, rainfall, or dew) for infection, and has an optimal temperature range around 10 to $15^{\circ} \mathrm{C}$ (Hoggas et al. 1969).

There is a need for more substantial analyses of field data to decide what weather factors and which best times for predicting. Disease-weather association could be identified and quantified by using the method 'Window Pane' as described by Coakley and Line (1982). Window Pane is a search algorithm used to identify a correlation between disease and weather variables during a certain period's frames. It has been applied to meteorological and rust data as described by Coakley et al. (1988) and Christensen et al. (1993). Most applications used regression analysis, however, a binary approach using discriminant analysis was introduced to identify disease epidemic associated with weather (Pietravalle et al. 2003). Identifying the variation in stripe rust infection associated to climatic factors could provide an overall index reflecting the expression of field resistance across varied locations. Further, it could offer a better idea about the variability in pathogen population joined with environmental conditions. The aim of this study was to assess the changeability in stripe rust infection beside grain yield of wheat under different climatic conditions and to determine how disease infection is associated to climatic variables.

\section{Materials and Methods}

\section{Stripe rust evaluation}

Stripe rust infections of ten Egyptian wheat cultivars, Sids-1, Sids-12, Sids-13, Gemmeiza-9, Gemmeiza-10, Gemmeiza-11, Giza-160, Giza168, Sakha-8, and Sakha-94, were investigated at adult plant stage under field condition. Two locations differ climatologically in Egypt were selected for the study i.e. Sakha, KafrEl-Sheikh Governorate, Lower Egypt $\left(31^{\circ} 5,12^{\prime}\right.$ N; $30^{\circ}$ 56' 49" E) and Sids, Beni-Suef Governorate, Upper Egypt (28०54'00” N; 30 57'00” E).

Env. Biodiv. Soil Security Vol. 2 (2018)
The experiments were carried out during two growing seasons (2016/17 and 2017/18) at the Experimental Farms of Sakha and Sids Agricultural Research Stations, Agricultural Research Center, Egypt. Sowing date was in mid-November. A split-plot design with three replicates (3 plots) was performed in this experiment. Main plots represented by wheat cultivars while subplots were infected and protected plants. The tested cultivars were sown in $3 \mathrm{~m}$ long rows ( 3 rows/plot for each cultivar) with $30 \mathrm{~cm}$ apart and $5 \mathrm{~g}$ seed rate for each row. Pre-infection with stripe rust, a complete protection using the fungicide Sumi-8 EC (5\% diniconazole, Sumitomo Corporation, Japan) at the rate of $0.35 \mathrm{ml} / \mathrm{L}$, was applied and repeated 2 times at 10 days intervals. Application was done in mid-February at the $7-8^{\text {th }}$ growth stages adopted by Large (1954). The experiment was surrounded by $1.5 \mathrm{~m}^{2}$ belt of the highly susceptible variety Morocco served as a spreader of natural infection and susceptible check. Cultural practices recommended for wheat crop were applied.

\section{Disease assessment}

At the disease onset until early dough stage (Large 1954), rust infection types were scored according to Roelfs et al. (1992)Rust severity was expressed as percentage coverage of leaves with rust pustules following Cobb's scale modified by Peterson et al. (1948). In late April of 2017 and 2018, final rust severity (FRS) was computed as disease severity (DS) for each cultivar in comparison with a universal highly susceptible cultivars "Morocco" (Das et al. 1993). Average coefficient of infection (ACI) was calculated according to Saari and Wilcoxson (1974) and Pathan and Park (2006) by multiplying of rust severity and constant values of infection type. The constant values for infection types were used based on; $\mathrm{R}=0.2, \mathrm{MR}=0.4$,MR-MS $=0.6$, $\mathrm{MS}=0.8$ and $\mathrm{S}=1.0$.

\section{Grain yield estimation}

At harvest, grain yields were estimated by 1000-grain weight for each cultivar at both locations. t. Grain weight loss (\%) was estimated according to Calpouzos et al. (1976) using the following equation:

$$
\text { Loss }(\%)=1-y d / y h \times 100
$$

where $y d=$ yield of diseased plants (infected); yh $=$ yield of healthy plant (protected). 


\section{Meteorological data}

Meteorological data for climatic factors i.e.temperature, relative humidity, rainfall and wind speed were pooled from the weather stations at Sakha and Sids Agricultural Research Stations during four months, January, February, March, and April in the years of 2017 and 2018. Means of data for each month during the period outlined were compared for the two locations under study. Discriminant analysis was used to classify the observations into two locations (Pietravalle et al. 2003). The method identified the climatic factors that determined the average coefficient of infection occurred.

\section{Statistical analysis}

The statistical analysis was done using SPSS computer program. Means were compared using LSD method (Steel and Torrie 1980). The correlation coefficient $(r)$ between the average coefficient of infection (ACI) and grain weight loss was calculated according to Pearson and Hartley (1970). Correlation matrix that determined the association between climatic factors and the average coefficient of infection was analyzed to identify which climatic factors influence disease infection has occurred.

\section{Results}

Stripe rust susceptibility

Data presented in Table 1 revealed variable levels of stripe rust infection among ten Egyptian wheat cultivars during two growing seasons at two locations (Sakha and Sids) differ climatologically in Egypt. The statistical analysis further showed highly significant differences in susceptibility levels of different wheat cultivars used in the study. Stripe rust infections for Sids location ranged from the $20 \mathrm{~S}$ to $90 \mathrm{~S}$ that were higher than those of Sakha location (TrMS to 70S). Regarding data for Sakha location, stripe rust infections during the first season up to $60 \mathrm{~S}$ in each of Giza160 and Sakha-8, were less than those of the second season, reaching 70S in each of Sids-12, Gemmeiza-11, Giza-160, and Sakha-8. In contrast with Sids location, the first season exhibited stripe rust infections reached the $90 \mathrm{~S}$ in Gemmeiza-11 that were higher than those of the second season up to $80 \mathrm{~S}$ in the same cultivar.

TABLE 1. Stripe rust infection of wheat cultivars under natural field condition at two locations differ climatologically in Egypt

\begin{tabular}{cccccc}
\hline \multirow{2}{*}{ Cultivar } & \multicolumn{4}{c}{ Stripe rust infection } \\
\cline { 2 - 3 } \cline { 2 - 3 } \cline { 5 - 6 } & \multicolumn{2}{c}{ Sakha location } & & \multicolumn{2}{c}{ Sids location } \\
\cline { 2 - 3 } Sids-1 & $\mathbf{1}^{\text {st }}$ season & $\mathbf{2}^{\text {nd }}$ season & & $\mathbf{1}^{\text {st }}$ season & $\mathbf{2}^{\text {nd }}$ season \\
Sids-12 & $10 \mathrm{~S}$ & $20 \mathrm{~S}$ & & $20 \mathrm{~S}$ & $30 \mathrm{~S}$ \\
Sids-13 & $50 \mathrm{~S}$ & $70 \mathrm{~S}$ & & $30 \mathrm{~S}$ & $40 \mathrm{~S}$ \\
Gemmeiza-9 & $10 \mathrm{~S}$ & $30 \mathrm{MS}$ & & $70 \mathrm{~S}$ & $60 \mathrm{~S}$ \\
Gemmeiza-10 & $30 \mathrm{~S}$ & $30 \mathrm{MS}$ & & $20 \mathrm{~S}$ & $20 \mathrm{~S}$ \\
Gemmeiza-11 & $10 \mathrm{MS}$ & $30 \mathrm{~S}$ & & $40 \mathrm{~S}$ & $30 \mathrm{~S}$ \\
Giza-160 & $50 \mathrm{~S}$ & $70 \mathrm{~S}$ & & $90 \mathrm{~S}$ & $80 \mathrm{~S}$ \\
Giza-168 & $60 \mathrm{~S}$ & $70 \mathrm{~S}$ & & $80 \mathrm{~S}$ & $70 \mathrm{~S}$ \\
Sakha-8 & $10 \mathrm{MS}$ & $10 \mathrm{~S}$ & & $30 \mathrm{~S}$ & $20 \mathrm{~S}$ \\
Sakha-94 & $60 \mathrm{~S}$ & $70 \mathrm{~S}$ & & $30 \mathrm{~S}$ & $20 \mathrm{~S}$ \\
\hline
\end{tabular}

Rust infection types were scored according to Roelfs et al. (1992) i.e. Immune (0), no visible symptoms; Resistant (R), necrotic/chlorotic stripes without sporulation; Moderately Resistant (MR), trace sporulation surrounded by necrotic/chlorotic stripes, Moderately Susceptible (MS), moderate sporulation surrounded by chlorotic stripes; Susceptible (S), sufficient sporulation with little or no chlorosis. Rust severity was expressed as percentage coverage of leaves with rust pustules following Cobb's scale modified by Peterson et al. (1948). 


\section{Rust infection and grain weight loss}

The performance of wheat cultivars in terms of average coefficient of infection (ACI) and grain weight loss during two seasons at two locations were shown in Table 2. Data analysis revealed significant differences in ACI and grain weight loss among wheat cultivars during both seasons for both locations. The ACI and grain weight loss for Sids location reaching 90 ACI (Gemmeiza-11), $23.12 \%$ (Giza-160), respectively, were higher than those of Sakha location up to 70 ACI and $16.72 \%$ in Giza-160. For Sakha location, the highest values of ACI were recorded with wheat cultivars, Giza-160 and Sakha- 8 during two seasons $(60,70 \mathrm{ACI}$ each, respectively) followed by Sids-12 and Gemmeiza-11 (50, 70 ACI each, respectively). The highest losses in grain weight during two seasons were recorded in Giza-160 with 13.69 and $16.72 \%$, respectively followed by Sakha- 8 with 10.92 and $12.68 \%$, respectively. For Sids location, Gemmeiza-11 exhibited the highest value of ACI during both seasons recording 90 and 80 , respectively. Giza-160 come in the second order $(80,70 \mathrm{ACI})$, followed by Sids-13 $(60,70$ ACI). Giza-160 still occupied the highest loss in grain weight during both seasons with 23.12 and $18.82 \%$, followed by Gemmeiza-11 (20.69 and 13.93\%) and Sids-13 (15.01 and 10.33\%), respectively.

\section{Climatological analysis}

Meteorological data about climatic factors into two location (Sakha and Sids) for four months, January, February, March, and April in the years of 2017 and 2018 were shown in Table 3. Climatological analysis indicated that values of rainfall and relative humidity for Sakha location were higher than those of Sids location, while, values of wind speed for Sids location were higher than that of Sakha location. Temperatures recorded at both locations were relatively close. Data analysis indicated the presence of climatic variation at both locations. The average coefficient of infection was associated with climatic factors atboth locations that exhibited ACI values for Sids location higher than those of Sakha location.

TABLE 2. Average coefficient of infection (ACI) and kernel weight loss (\%) of wheat cultivars naturally infected with stripe rust at two locations differ climatologically in Egypt.

\begin{tabular}{|c|c|c|c|c|c|c|c|c|}
\hline \multirow{3}{*}{ Cultivar } & \multicolumn{4}{|c|}{ Average coefficient of infection (ACI) } & \multicolumn{4}{|c|}{ Kernel weight loss $(\%)$} \\
\hline & \multicolumn{2}{|c|}{ Sakha location } & \multicolumn{2}{|c|}{ Sids location } & \multicolumn{2}{|c|}{ Sakha location } & \multicolumn{2}{|c|}{ Sids location } \\
\hline & $1^{\text {st }}$ season & $2^{\text {nd }}$ season & $1^{\text {st }}$ season & $2^{\text {nd }}$ season & $1^{\text {st }}$ season & $2^{\text {nd }}$ season & $1^{\text {st }}$ season & $2^{\text {nd }}$ season \\
\hline Sids-1 & $10 \mathrm{cB}$ & 20 bcdAB & $20 \mathrm{dAB}$ & $30 \mathrm{cdA}$ & $5.07 \mathrm{dc}$ & $6.58 \mathrm{efB}$ & $6.06 \mathrm{fgBC}$ & $10.75 \mathrm{cA}$ \\
\hline Sids-12 & $50 \mathrm{abB}$ & $70 \mathrm{aA}$ & $30 \mathrm{cdC}$ & $40 \mathrm{cBC}$ & $8.85 \mathrm{cB}$ & $12.89 \mathrm{bA}$ & $5.00 \mathrm{gD}$ & $7.44 \mathrm{dC}$ \\
\hline Sids-13 & $10 \mathrm{cB}$ & $24 \mathrm{bcB}$ & $70 \mathrm{bA}$ & $60 \mathrm{bA}$ & $4.66 \mathrm{dD}$ & $7.82 \mathrm{deC}$ & $15.01 \mathrm{cA}$ & $10.33 \mathrm{cB}$ \\
\hline Gemmeiza-9 & $30 \mathrm{bA}$ & $24 \mathrm{bcB}$ & $20 \mathrm{~dB}$ & $20 \mathrm{~dB}$ & $8.65 \mathrm{cA}$ & $7.02 \mathrm{deB}$ & $7.95 \mathrm{eAB}$ & $8.40 \mathrm{dA}$ \\
\hline Gemmeiza-10 & $8 \mathrm{cB}$ & $30 \mathrm{bA}$ & $40 \mathrm{cA}$ & $30 \mathrm{cdA}$ & $2.93 \mathrm{fD}$ & $5.14 \mathrm{gC}$ & $10.60 \mathrm{dA}$ & $7.38 \mathrm{~dB}$ \\
\hline Gemmeiza-11 & $50 \mathrm{abC}$ & $70 \mathrm{aB}$ & $90 \mathrm{aA}$ & $80 \mathrm{aAB}$ & $8.59 \mathrm{cD}$ & $11.11 \mathrm{cC}$ & $20.69 \mathrm{bA}$ & $13.93 \mathrm{bB}$ \\
\hline Giza-160 & $60 \mathrm{aB}$ & $70 \mathrm{aAB}$ & $80 \mathrm{abA}$ & $70 \mathrm{abAB}$ & $13.69 \mathrm{aD}$ & $16.72 \mathrm{aC}$ & $23.12 \mathrm{aA}$ & $18.82 \mathrm{aB}$ \\
\hline Giza-168 & $8 \mathrm{cB}$ & $10 \mathrm{cdB}$ & $30 \mathrm{cdA}$ & $20 \mathrm{dAB}$ & $4.33 \mathrm{deC}$ & $7.89 \mathrm{dA}$ & $8.41 \mathrm{eA}$ & $5.87 \mathrm{eB}$ \\
\hline Sakha-8 & $60 \mathrm{aB}$ & $70 \mathrm{aA}$ & $30 \mathrm{cdC}$ & $20 \mathrm{dC}$ & $10.92 \mathrm{bB}$ & $12.68 \mathrm{bA}$ & $10.41 \mathrm{~dB}$ & $4.62 \mathrm{fC}$ \\
\hline Sakha-94 & $2.4 \mathrm{cB}$ & $8 \mathrm{~dB}$ & $30 \mathrm{cdA}$ & $30 \mathrm{cdA}$ & $3.23 \mathrm{efC}$ & $5.76 \mathrm{fgAB}$ & $6.63 \mathrm{fA}$ & $5.03 \mathrm{efB}$ \\
\hline LSD (0.05) & & 14 & & & & & & \\
\hline
\end{tabular}

Env. Biodiv. Soil Security Vol. 2 (2018) 
TABLE 3. Meteorological data recorded during four months Jan, Feb, Mar, Apr in 2017 and 2018 at Sakha and Sids locations in Egypt.

\begin{tabular}{|c|c|c|c|c|c|c|c|c|c|}
\hline \multirow{2}{*}{ Year } & \multirow{2}{*}{ Month } & \multicolumn{2}{|c|}{ Temperature $\left({ }^{\circ} \mathrm{C}\right)$} & \multicolumn{2}{|c|}{ Humidity (\%) } & \multicolumn{2}{|c|}{ Rainfall (mm) } & \multicolumn{2}{|c|}{ Wind speed $(\mathrm{m} / \mathrm{s})$} \\
\hline & & Sakha & Sids & Sakha & Sids & Sakha & Sids & Sakha & Sids \\
\hline \multirow{4}{*}{ 혹 } & Jan & 14.40 & 14.10 & 69.3 & 56.25 & 8.40 & 4.82 & 1.37 & 2.92 \\
\hline & Feb & 13.70 & 15.90 & 70.0 & 50.5 & 5.90 & 0.25 & 1.49 & 3.87 \\
\hline & Mar & 17.20 & 19.75 & 60.2 & 43.6 & 3.50 & 0 & 1.45 & 2.98 \\
\hline & Apr & 18.50 & 21.40 & 61.8 & 41.35 & 0 & 0 & 1.25 & 2.83 \\
\hline \multirow{4}{*}{$\stackrel{\infty}{\bar{\sim}}$} & Jan & 14.50 & 14.60 & 69.3 & 62.25 & 10.50 & 0 & 2.04 & 2.05 \\
\hline & Feb & 15.20 & 15.60 & 69.5 & 59.3 & 5.40 & 5.07 & 2.29 & 2.80 \\
\hline & Mar & 16.80 & 18.80 & 62.4 & 48.5 & 2.40 & 0.63 & 2.85 & 3.09 \\
\hline & Apr & 18.20 & 22.70 & 61.2 & 41.95 & 0 & 0 & 2.80 & 3.12 \\
\hline
\end{tabular}

Correlation of rust infection and grain weight loss

The correlation coefficient $(r)$ analysis illustrated in Fig. 1 and 2 revealed that the grain weight loss was strongly associated with an average coefficient of infection (ACI) among the tested wheat cultivars for both locations. A strong positive correlation was observed between the average coefficient of infection and grain weight loss of stripe rust-infected wheat recording $r=0.9044$ for Sakha location and $r=0.8866$ for Sids location.
Correlation of rust infection and climatic factors

The correlation matrix shown in Tables 4 and 5 indicated the presence of an association between $\mathrm{ACI}$ and climatic factors into both locations we analyzed. The temperature was the main limiting factor for the occurrence of a stripe rust infection expressed in ACI (negatively associated), followed by relative humidity (positively associated). Positive association present between ACI and rainfall was relatively close to both locations, while positive association present between ACI and wind speed was higher at Sids location than that of Sakha location.

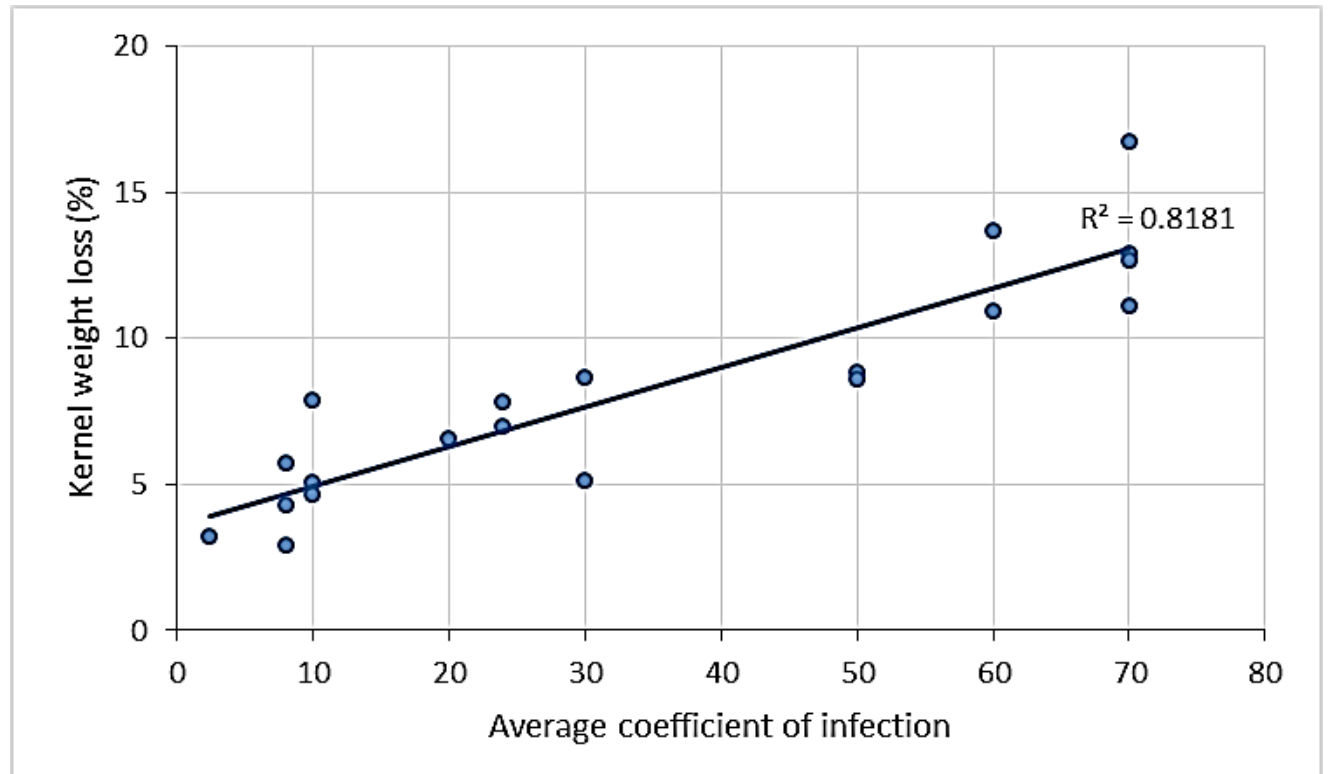

Fig.1. A strong positive correlation $(r=0.9044)$ between the average coefficient of infection and grain weight loss of stripe rust-infected wheat at Sakha location for both seasons.

Env. Biodiv. Soil Security Vol. 2 (2018) 


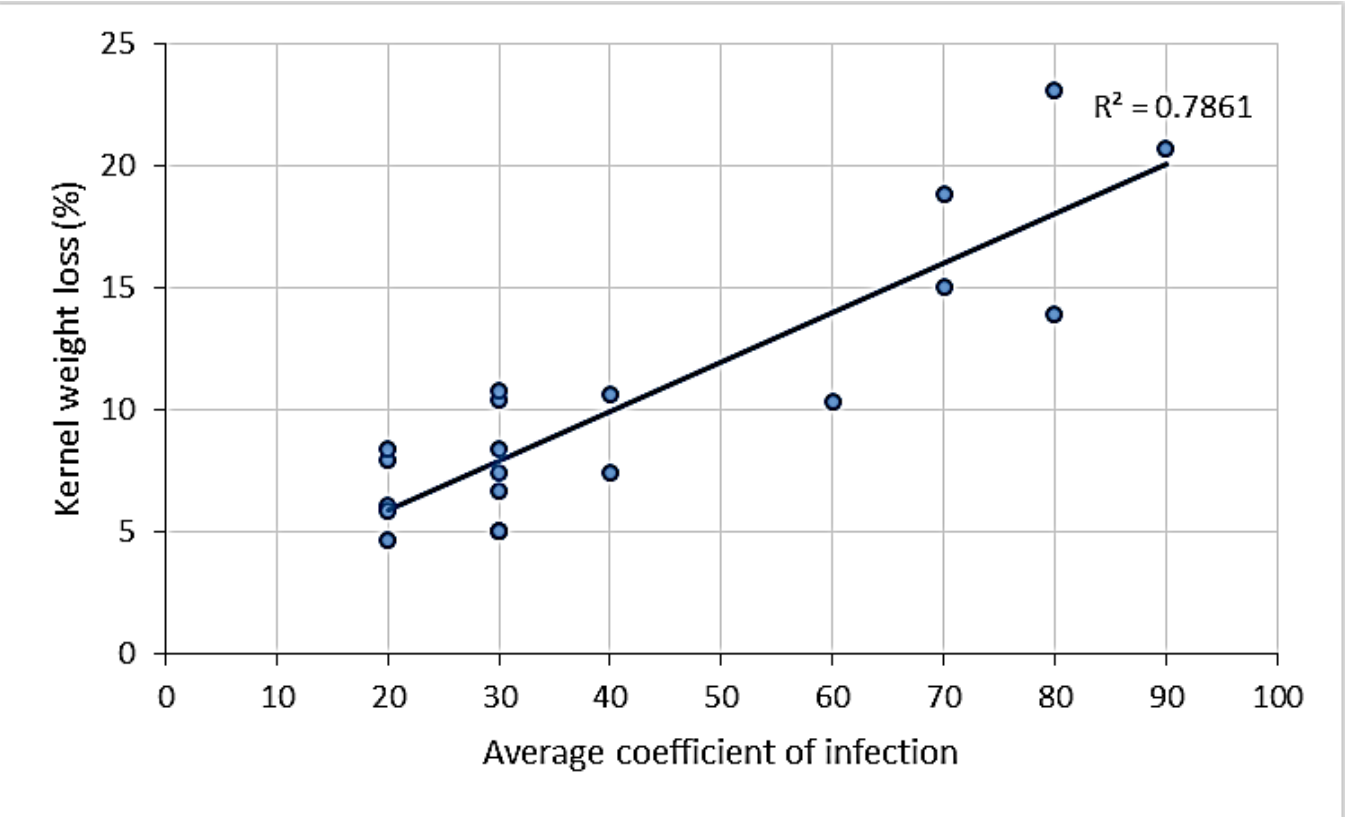

Fig. 2. A strong positive correlation $(r=0.8866)$ between the average coefficient of infection and grain weight loss of stripe rust-infected wheat at Sids location for both seasons.

TABLE 4.Correlation matrix indicates the average coefficient of infection (ACI) for wheat stripe rust associated with climatic factors at Sakha location in Egypt.

\begin{tabular}{lccccc}
\hline Factor & Temperature & Humidity & Rainfall & Wind speed & ACI \\
\hline Temperature & 1 & -0.93104 & -0.88488 & 0.217406 & -0.49958 \\
Humidity & -0.93104 & 1 & 0.820963 & -0.18958 & 0.341855 \\
Rainfall & -0.88488 & 0.820963 & 1 & -0.24051 & 0.242081 \\
Wind speed & 0.217406 & -0.18958 & -0.24051 & 1 & 0.160255 \\
ACI & -0.49958 & 0.341855 & 0.242081 & 0.160255 & 1 \\
\hline
\end{tabular}

TABLE 5. Correlation matrix indicates the average coefficient of infection (ACI) for wheat stripe rust associated with climatic factors at Sids location in Egypt

\begin{tabular}{lccccc}
\hline Factor & Temperature & Humidity & Rainfall & Wind speed & ACI \\
\hline Temperature & 1 & -0.91554 & -0.57881 & 0.190822 & -0.5322 \\
Humidity & -0.91554 & 1 & 0.565982 & -0.45733 & 0.435318 \\
Rainfall & -0.57881 & 0.565982 & 1 & -0.08561 & 0.232131 \\
Wind speed & 0.190822 & -0.45733 & -0.08561 & 1 & 0.426516 \\
ACI & -0.5322 & 0.435318 & 0.232131 & 0.426516 & 1 \\
\hline
\end{tabular}

Env. Biodiv. Soil Security Vol. 2 (2018) 


\section{Discussion}

The stripe rust infection of ten Egyptian wheat cultivars was investigated under the circumstances of field conditions during two seasons at two locations (Sakha and Sids)differ climatologically in Egypt. Variable levels of disease infection followed by significant reducing in grain weight were recorded of all the cultivars used in the experiment. Stripe rust infections for Sids location ranged from $20 \mathrm{~S}$ to $90 \mathrm{~S}$ were higher than those of Sakha location, ranging from TrMS to 70S. The average coefficient of infection (ACI) is a common expression of disease severity and host reaction for specific studies, ACI can be used as a criterion for a selection from large populations. Yield losses due to stripe rust varied among genotypes and locations with an overall range from 12.7-87\% (Bolat and Altay 2007). In our study, the average coefficient of infection (ACI) and grain weight loss for Sids location reaching 90 ACI (Gemmeiza-11) and 23.12\% (Giza160), were higher than those of Sakha location up to $70 \mathrm{ACI}$ and $16.72 \%$ in Giza- 160 . These results seemed to be logical with susceptible cultivars. Yield losses increase proportionately with the increase in the severity of the disease (Salman et al. 2006) and a negative relationship between yield and stripe rust severity has been reported (King 1976, Cortazar 1984, Schultz and Line 1992, Murray et al. 1994). Our findings revealed that the grain weight loss was strongly associated with ACI among the tested wheat cultivars for both locations. The correlation coefficient (r) analysis showed a strong positive correlation between the average coefficient of infection and grain weight loss of stripe rust-infected wheat, recording $\mathrm{r}=0.9044$ for Sakha location and $\mathrm{r}=0.8866$ for Sids location. Bolat and Altay (2007) reported a negative correlation between yield and ACI, implying significant increases in yield losses as ACI rise. Also, Afzal et al. (2008) recorded a strong negative correlation (-0.9185) between the disease level and 1000-grain weight of wheat.

Climate changes limit wheat crop production through their effected role in the occurrence and severity of plant diseases (Junk et al. 2016). The growth and progress rate of stripe rust pathogen is influenced by weather variability, affecting the epidemic development. Likewise, the differences in weather variables across locations create a significant difference in yellow rust severity among the wheat varieties (Alemu and Fininsa 2016). In our study, climatic factors into two locations (Sakha and Sids) differ climatologically in Egypt were recorded for the first four months (January, February, March, and April) in the years of 2017 and 2018. Climatic variations were recorded at both locations. Rainfall and relative humidity for Sakha location were higher than those of Sids location while wind speed for Sids location was higher than that of Sakha location. Temperatures were relatively close at both locations. The average coefficient of infection was associated with climatic factors at both locations that exhibited ACI values for Sids location higher than those of Sakha location. Correlation analysis showed an association between ACI and climatic factors into both locations. The temperature was the main limiting factor for the occurrence of a stripe rust infection expressed in ACI (negatively associated), followed by relative humidity (positively associated). The positive association between ACI and rainfall was relatively close to both locations while positive association present between ACI and wind speed was higher at Sids location than that of Sakha location. This suggested that high wind speed may play an important role in the dispersal of urediniospores of the pathogen between wheat plants than the other factors. Previous studies of Jones and Clifford (1983), Wiese 1987 and Beest et al. (2008) reported that wind plays an important role in the dispersal. Urediniospores have the capacity for wind dispersal over long distances, which may, under high inoculum pressure, extend to thousands of kilometers from the initial infection sites (Chen et al. 2014). The high disease infection was associated with wind speed into Sids location. This suggests the effect of wind on dispersal is stronger than the effect of wind on humidity. Mild winters and springs favored the biotroph yellow rust (Wiik and Ewaldz 2009). Junk et al. (2016) reported that under the favorable weather, rust spores are produced in great numbers and they can be blown vast distances by the wind.

The phenomenon may be attributed to relatively more rainfall at Sakha location in comparison with Sids location. The results are in line with the previous works (Afzal et al. 2008) which shows that disease severity is affected by meteorological factors such as temperature, humidity rainfall, and wind speed. Smith et al. (1986) estimated a 51\% reduction in grain yield due to stripe rust infection on the well-watered plots and a $46 \%$ loss on rainfed plots. Although, infection efficiency, sporulation capacity, lesion expansion rate, latent period and infectious period 
are the most considered components for disease assessment, however, the disease was more strongly affected by initial disease and weather (Luo and Zeng 1995). Murray et al (1994) reported that grain yield was negatively correlated with the proportion of leaf area affected by stripe rust infection during grain development at the end of heading to late milk. There were two factors affected this relationship, where the loss in grain yield increased as the length of the epidemic increased, while decreased as temperature increased.

The temperature range for stripe rust is optimal between 10 and $15^{\circ} \mathrm{C}$ with limits near 0 and $21^{\circ} \mathrm{C}$; temperatures higher than $23^{\circ} \mathrm{C}$ will slow down an infection (Hoggas et al. 1969; Wiese 1987). In our study, the associations were found to correspond with this temperature range. The temperature was the main limiting factor for the infection level of wheat stripe rust at both locations we studied. Papastamati and Bosch (2006) reported that temperature was the most important variable for the progress of stripe rust. Christensen et al. (1993) found that the temperature in January and February was positively correlated with yellow rust severity. Coakley et al. (1988) reported a positive association between disease severity and the average temperature in January, followed by a negative association with the number of days above $25^{\circ} \mathrm{C}$ in May and June. In our results, an optimal temperature was associated with higher disease infection. This suggests that temperature is a limiting factor correspondent with the months of January, February and March. Unlike to Beest et al. (2008) who did not find a negative relationship between high temperatures and yellow rust in England. Also, Gladders et al. (2007) reported that the most important factor for stripe rust infections later in the season was a high winter temperature associated with overwintering. This probably because the temperature seldom exceeded the $25^{\circ} \mathrm{C}$ in such regions. Nevertheless, stripe rust epidemics are sometimes halted by periods of hot weather but mainly after growth stage 65 (flowering half complete). Coakley et al. (1988) reported that stripe rust infection in the Pacific Northwest of the United States was positively associated with winter temperature while was negatively associated with summer temperature. The emergence of new pathotypes of P. striiformis adapted to high temperatures have expanded virulence profiles more aggressive, leading to wide-scale epidemics (Bueno-Sancho et al. 2017). The temperature in January and February have a direct effect on stripe rust due to the survival infected wheat leaves and shortening the latent period of the fungus. In the short latent period, the fungus can spread more rapidly to healthy plants. The latent period for P. striiformis decreases as the temperature increases (Coakley 1978).

The stripe rust development is associated with another requirement like the availability of free moisture which can be high humidity, rainfall, or dew (Jones and Clifford 1983; Wiese 1987). No relationship is in line with this in the UK, suggesting that the availability of free moisture is not a limiting factor (Beest et al. 2008). This may be because UK weather is characterized by periods of anti-cyclonic weather, alternating with frontal systems carrying rain and thus dew forms overnight. In the present study, another association found with disease severity was rainfall. Heavy rainfall was present into Sakha location in contrast with that of Sids location. Where ACI occurred in Sakha location was lower than that of Sids location. This suggests that heavy rainfall may have opposing effects. Heavy rain is often followed by high relative humidity, creating good conditions for the disease, but rain can also wash away spores (Merchan and Kranz 1986). The relationship between a disease scoring scale and yield loss is not straightforward that climatic elements influence disease indices and yield loss correlated (Jevtic et al. 2017).

The changeability in stripe rust infection and yield loss of wheat cultivars across different locations should not be ignored, considering climatic factors influencing. Thus, the impact of each should be analyzed as part of the environmental system. Although, climatic conditions at both locations we studied were favorable for stripe rust. However, results gave evidence that climatic variables influenced the severity of stripe rust and grain yield associated. Considering the climatic variation at the locations that have increased in the disease severity or frequency is of great benefits for epidemiological studies. In addition, the quantitative assessments of yield losses should be routinely collected to facilitate climatological plant pathological research. Such impacts may be useful for defining suitable agronomic adaptation strategies like right cultivar choice, or shifts in the sowing date to minimize or avoid negative effects on crop production. 
Compliance with ethical standards:

This article does not contain any studies with human participants or animals performed by any of the authors.

\section{Conflict of Interest}

The authors declare that they have no conflicts of interest.

\section{$\underline{\text { References }}$}

Afzal SN, Haque MI, Ahmedani MS, Rauf A, Munir M, Firdous SS, Rattu A, Ahmad I (2008) Impact of stripe rust on grain weight of wheat varieties sown in rainfed areas of Pakistan. Pak J Bot 40 (2): 923929

Alemu W, Fininsa C (2016)Effects of environment on wheat varieties, yellow rust resistance, yield and yield related traits in South-Eastern Ethiopia. Plant 4 (3): $14-22$

Beard C, Thomas G, Loughman R, Jayasena K(2007) Managing stripe rust and leaf rust of wheat. Farmnote No. 43/2005. Department of Agriculture, Government of Western Australia.

Bolat N, Altay F (2007) Comparison of different methods used in calculating the effect of stripe rust on wheat grain yields. Acta Agronomica Hungarica, 55: 89-98.

Browder LE, Eversmeyer MG(1986) Interactions of temperature and time with some Puccinia recondita: Triticum corresponding gene pairs. Phytopathology p. 76.

Bueno-Sancho V, Persoons A, Hubbard A, CabreraQuio LE, Lewis CM, Corredor-Moreno P, Bunting DCE, Ali S, Chng S, Hodson DP, Burrows RM, Bryson R, Thomas J, Holdgate S, Saunders DGO (2017) Pathogenomic analysis of wheat yellow rust lineages detects seasonal variation and host specificity. Genome Biology and Evolution 9 (12): 3282-3296. doi, 10.1093/gbe/evx241

Calpouzos L, Roelfs AP, Maolison ME, Martin FB, Welsh JR, Wilcoxson RD (1976) A new model to measure. Yield losses caused by stem rust in spring wheat. Minn. Agric. Exp. Stn. Tech. Bull. 307 (123).

Chen W, Wellings C, Chen X, Kang Z, Liu T (2014) Wheat stripe (yellow) rust caused by Puccinia striiformis f. sp. tritici. Mol Plant Pathol. 15 (5):433-446. doi: 10.1111/mpp.12116.

Chen X.M. (2005) Epidemiology and control of stripe rust [Pucciniastriiformisf.sp. tritici] on wheat. Canadian Journal of Plant Pathology, 27: 314337.

Christensen K, Jorgensen LN, Secher BJM(1993) Development of a yellow rust model based on historical data. Pages 71-78 in: Proceeding of the $10^{\text {th Danish }}$ Plant Protection Conference. Plantevaernscentret, Lyngby, Denmark.

Coakley SM (1978) The effect of climate variability on stripe rust of wheat in the Pacific Northwest. Phytopathology 68: 207-212.

Coakley SM, Line RF(1982) Prediction of stripe rust epidemics on winter wheat using statistical models. Phytopathology 72: 1006.

Coakley SM, Line RF, McDaniel LR (1988) Predicting stripe rust severity on winter wheat using an improved method for analyzing meteorological and rust data. Phytopathology 78: 543-550.

Cortazar SR (1984) Effects of rusts on yield and hectolitre weight in wheat in two regional trials at the La Platina Experimental Station. Agricultura Tecnika 44: 275-280

Das MK, Rajaram S, Ktonstad WK, MundtCC, Singh RP (1993) Associations and genetics of three components of slow rusting in leaf rust of wheat. Euphytica 68 (112): 9-109.

de Vallavieille-Pope C, Ali S, Leconte M, Enjalbert J, Delos M (2012) Virulence dynamics and regional structuring of Pucciniastriiformis f. sp. tritici in France between 1984 and 2009. Plant Dis 96 (1): $131-140$

de Vallavieille-Pope CL, Leconte M, Goyeau H (1995) Comparative effects of temperature and interrupted wet periods on germination, penetration, and infection of Puccinia recondita f.sp. tritici and $P$. striiformis on wheat seedlings. Phytopathology, 85: 409-415.

Draz IS Abou-Elseoud MS, Kamara AM, AlaaEldeinOmaima A, El-Bebany AF (2015) Screening of wheat genotypes for leaf rust resistance along with grain yield. Annals of Agricultural Science, 60 (1): 29-39.

Draz IS, 2019. Pathotypic and molecular evolution of contemporary population of Pucciniastriiformisf. sp. triticiin Egypt during 2016-2018. J Phytopathol. 167: 26-34. https://doi.org/10.1111/ iph. 12770

El-Daoudi YH, Ikhlas Shafik, Ghamem EH, Abu El-

Env. Biodiv. Soil Security Vol. 2 (2018) 
Naga SA, Sherif SO, Khalifa MMO, Mitkees RA, Bassiouni AA (1996) Stripe rust occurrence in Egypt and assessment of grain yield loss in 1995. Proceedings Du Symposium Regional Sur les Maladies des Cerales et des Legumineuses Alimentaries 11-14 Nov 1996, Rabat, Maroc.

Gladders P, Langton SD, Barrie IA, Taylor MC, Paveley ND(2007) The importance of weather and agronomic factors for the overwinter survival of yellow rust (Puccinia striiformis) and subsequent disease risk in commercial wheat crops in England. Ann Appl Biol 150: 371-382.

Hoggs WH, Houman CE, Mallik AK, Zadoks JC(1969) Meteorological factors affecting the epidemiology of wheat rusts. World Meteorological Organization, Geneva, Switzerland.

Hovmøller MS, Sørensen CK, Walter S, Justesen AF(2011) Diversity of Puccinia striiformison cereals and grasses. Annual Review of Phytopathology 49: 197-217.

Hovmøller MS, Walter S, Justesen AF (2010) Escalating threat of wheat rusts. Science 329 (5990): 369.

Jevtic R, ZupunskiV, LalosevicM, ZupunskiL (2017) Predicting potential winter wheat yield losses caused by multiple disease systems and climatic conditions. Crop Prot 99: 17-25

Jones DG, Clifford BC(1983) Cereal Disease. Their

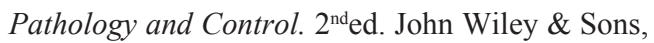
New York.

Junk J, Kouadio L, Delfosse P, El Jarroudi M (2016) Effects of regional climate change on brown rust disease in winter wheat. Climatic Change 135 (34): 439-451

King JE (1976) Relationship between yield losses and severity of yellow rust recorded on a large number of single stems of winter wheat. Plant Pathol. 25: 172-177.

Kolmer JA (1996) Genetics of resistance to leaf rust. Annual Review of Phytopathology 34: 435-455.

Large EC (1954) Growth Stages in Cereals: IIIustration of Feekes scale Plant Pathol. 3:128-129.

Lyon B, Broders K (2017) Impact of climate change and race evolution on the epidemiology and ecology of stripe rust in Central and Eastern USA and Canada. Canadian Journal of Plant Pathology 39 (4): 385-392

MerchanVM, Kranz J(1986) The effect of rain on the development of wheat powdery mildew (Erysiphe-graminis Dc f. sp. tritici). Zeitschrift Fur Pflanzenkrankheiten Und Pflanzenschutz-J. Plant Dis Prot 93: 262-270.

Murray GM, Ellison PJ, Watson A, Cullis BR (1994) The relationship between wheat yield and stripe rust as affected by length of epidemic and temperature at the grain development stage of crop growth. Plant Pathol. 43: 397-405.

Papastamati K, Van den Bosch F(2006) The sensitivity of the epidemic growth rate to weather variables, with application to yellow rust on wheat. Phytopathology 94: 202-210.

Pathan AK, Park RF (2006) Evaluation of seedling and adult plant resistance to leaf rust in European wheat cultivars. Euphytica 149: 327-342.

Pearson EM, Hartley HO (1970) Biometrial Tables for Statisticians. The $3^{\text {th }}$ edition, Vol. I, University Press, New York, Cambridge, pp. 270.

Peterson RF, Campbell AB, Hannah AE (1948) A diagrammatic scale for rust intensity on leaves and stems of cereals. Can. J. Res. 26: 496-500.

Pietravalle S, Shaw MW, Parker SR, van den Bosch F (2003) Modeling of relationships between weather and Septoria tritici epidemics on winter wheat: A critical approach. Phytopathology 93:13291339-.

Roelfs AP, Singh RP, Saari EE (1992) Rust Diseases of Wheat: Concepts and Methods of Disease Management. CIMMYT, Mexico. 81 pp.

Saari EE, Wilcoxson RD (1974) Plant disease situation of high-yielding durum wheat in Asia and Africa. Annual Review of Phytopathology 12:49-68.

Schultz TR, Line RF (1992) High-temperature, adult plant resistance to wheat stripe rust and effects on yield components. Agronomy Journal: 84, 170-175

Singh RP, William HM, Huerta-Espino J, Rosewarne G (2004) Wheat rust in Asia: meeting the challenges with old and new technologies. In Proceedings of the $4^{\text {th }}$ International Crop Science Congress, New Directions for a Diverse Planet; 26 Sep - 1 Oct 2004; Brisbane, Australia. pp. 1-13.

Steel RGD, Torrie JH (1980) Principles and Procedures of Statistics, 2nd ed. Mc Graw Hill BookCompany, New York.

TeBeest DE, Paveley ND, Shaw MW, van den Bosch F(2008) Disease-weather relationships for powdery mildew and yellow rust on winter wheat.

Env. Biodiv. Soil Security Vol. 2 (2018) 
Phytopathology 98: 609-617.

Wiese MV(1987) Compendium of Wheat Diseases. $2^{\text {nded. }}$ American Phytopathological Society, St. Paul, MN.
Young CS, Paveley ND, Vaughan TB, Thomas JM, Lockley KD(2003) Predicting epidemics of yellow rust (Puccinia striiformis) on the upper canopy of wheat from disease observations on lower leaves. Plant Pathol. 52: 338-349.

(Received 14/12/2018; accepted 10/1/2019) 